\title{
SEED GERMINATION AND RADICLE ESTABLISHMENT RELATED TO TYPE AND LEVEL OF SALT IN COMMON BEAN (PHASEOLUS VULGARIS L. VAR. DJEDIDA)
}

\author{
L.M. MANSOURI ${ }^{1}$, N. HELEILI ${ }^{2}$, Z.F. BOUKHATEM ${ }^{3}$, A. KHELOUFI $^{{ }^{*}}$
}

*E-mail: abdenour.kheloufi@yahoo.fr

Received: Oct. 25, 2019. Revised: Nov. 21, 2019. Accepted: Nov. 28, 2019. Published online: Dec. 20, 2019

\begin{abstract}
Saline soils contain multiple types of salt, each of them may exert a different effect on seed germination and seedling growth. The aim of this study is to assess the effects of five types of salt on the seed germination and radicle establishment of common bean
\end{abstract} (Phaseolus vulgaris L. var. Djedida). The experiment was set out as a factorial experiment based on completely randomized design with four replications of ten seeds for the seed germination and twelve replicates for the seedling growth. We used five kinds of salts $(\mathrm{NaCl}$, $\mathrm{Na}_{2} \mathrm{SO}_{4}, \mathrm{CaCl}_{2}, \mathrm{CaCO}_{3}$ and $\mathrm{KCl}$ ) with concentrations of $0,100,200$ and $300 \mathrm{mM}$. Seeds were incubated in Petri dishes at $25^{\circ} \mathrm{C}$, in the dark, for 10 days. The results of analysis of variance indicated that the effects of salt types and concentrations, and their interaction effect were significant in all measured traits $(P<0.01)$. However, no significance effect was found on secondary roots number and seedlings dry biomass with $\mathrm{CaCO}_{3}$ treatment solution. According to the results, the inhibitory effects of the five salt types differed significantly. Indeed, germination of common bean seeds by various salts were in the order of $\mathrm{NaCl}>$ $\mathrm{KCl}>\mathrm{CaCO}_{3}>\mathrm{Na}_{2} \mathrm{SO}_{4}>\mathrm{CaCl}_{2}$. However, the taproot length, the number of secondary roots and the seedlings dry weight by various salts were in the order of $\mathrm{CaCO}_{3}>\mathrm{KCl}>\mathrm{NaCl}>\mathrm{CaCl}_{2}>$ $\mathrm{Na}_{2} \mathrm{SO}_{4}$. The effect of salt concentration was also obvious. The reduction in dry biomass of cotyledons is proportional to germination rates and to the development of seedlings in dry biomass and in size. Seeds of P. vulgaris var. Djedida were able to germinate under all concentrations of the various types of salt. The lowest final germination percentage (FGP) was obtained under $300 \mathrm{mM}$ of all salts recording the following values: $\mathrm{CaCO}_{3}$ $60 \%, \mathrm{NaCl}-60 \%, \mathrm{KCl}-52.5 \%, \mathrm{Na}_{2} \mathrm{SO}_{4}-$ $50 \%$ and $\mathrm{CaCl}_{2}-27.5 \%$. During

\footnotetext{
${ }^{1}$ Department of Ecology and Environment, University of Batna 2, Batna, Algeria

2 Department of Veterinary Sciences, University of Batna 1, Batna, Algeria

${ }^{3}$ Department of Biotechnology, University of Oran 1, Oran, Algeria
} 
germination stage, the radicle emergence would be controlled by the environment osmolarity, while the later growth of the seedling would be limited by the reserve mobilization.

Keywords: agriculture; Fabaceae; local adaptation; osmotic stress; salt tolerance.

\section{INTRODUCTION}

Food legumes play an important role in the cropping systems and in the diet of the population (Sinclair and Vadez, 2012). Among these legumes, bean or common bean (Phaseolus vulgaris L.) is one of the oldest species and a major part of humanity's diet (Bevilaqua and Antunes, 2015). In addition to its interest as one of the major legumes providing energy, beans are also an important source of protein in developing countries (Blair, 2013).

In Algeria, the low yields are mainly due to the environment fluctuations recorded during the various seasons (Beebe et al., 2013). Indeed, the Algerian climate is characterized by irregular rainfall over time and space, as well as a tendency towards more aridity and thus an increased impact of drought. These are considered as factors of a partial or total loss of production (Faramarzi et al., 2013).

Abiotic stresses, such as drought, salinity, extreme temperatures, chemical toxicity and oxidative stress are serious threats to agriculture and result in a deterioration of the environment (Kusvuran et al., 2016). Abiotic stress is the leading cause of crop loss in the world, reducing average yields of most field crops (Lobell, 2014). Drought and salinity are becoming widespread in many areas and can result in serious salinization of more than $50 \%$ of all arable land by 2050 (Galford et al., 2010). Abiotic stress results in a series of morphological, physiological, biochemical and molecular changes that affect plant growth and productivity (Zandalinas et al., 2018). Overall, more than 800 million hectares of land are affected by salinity (Munns, 2005), at the world level.

Saline soils contain multiple types of soluble salt components, each of which has a different effect on the initial growth of plants (Bernstein, 1958; Munns and Termaat, 1986; Shannon and Grieve, 1998; Kheloufi et al., 2016a), and the compositions of soluble salts in saline soils differ greatly among locations (Tobe et al., 2002; Kheloufi et al., 2017).

Although most of these reports are basing on experiments with $\mathrm{NaCl}$, it has been hypothesized that the other salts have similar effects on cellular function, but to different degrees (Tobe et al., 2004). More cations and anions associated with salinity are calcium $\left(\mathrm{Ca}^{2+}\right)$, magnesium $\left(\mathrm{Mg}^{2+}\right)$, sodium $\left(\mathrm{Na}^{+}\right)$, chloride $\left(\mathrm{Cl}^{-}\right)$, sulfate $\left(\mathrm{SO}_{4}{ }^{2-}\right)$, and bicarbonate $\left(\mathrm{HCO}_{3}{ }^{-}\right)$. In some instances, potassium $\left(\mathrm{K}^{+}\right)$and nitrate $\left(\mathrm{NO}_{3}{ }^{-}\right)$may participate to salinity, and when $\mathrm{pH}$ is greater than $9, \mathrm{CO}_{3}{ }^{2-}$ becomes a problematic anion (Schabes and Sigstad, 2005). These effects of salts on the functions of the 
cell membranes and the cell walls may affect the water potential of the cytosol and cellular extensibility, and thus, may affect seed germination and seedling growth (Kheloufi et al., 2018).

Seed germination is the most important stage in a plant life cycle. Water, air, temperature and light are all essential for the seed germination process, starting from imbibition, activation and succeeding manifesttation (Bradford, 1995; Bewley and Black, 2012; Finch-Savage and Bassel, 2015).

In glycophytes species, salinity can reduce the growth of plants or damage the plants through osmotic effect (it causes water deficit), toxic effects of ions and imbalance of the uptake of essential nutrients (Parihar et al., 2015).

In the present study, we compared the effects of different types of salts on seed germination and seedling growth of common bean (Phaseolus vulgaris var. Djedida). This variety is among the most cultivated bean varieties in Algeria. It has already been the subject of several studies evaluating its tolerance to $\mathrm{NaCl}$ (Bouzid and Rahmoune, 2012; Adda et al., 2014; Taïbi et al., 2016) and even seawater (Mansouri and Kheloufi, 2017).

\section{MATERIAL AND METHODS}

\section{Experimental design and treatments}

This research project was performed in 2018, at the laboratory of the Department of Ecology and Environment, University of Batna 2, Algeria. Seeds of
P. vulgaris var. Djedida (length: $12.9 \pm$ $0.63 \mathrm{~mm}$; width: $6.46 \pm 0.51 \mathrm{~mm}$; thickness: $5.69 \pm 0.42 \mathrm{~mm}$; mean $\pm \mathrm{SE}$; $\mathrm{n}=50$ ) were provided by SARL AGROSEED (Harvest date: 2016; seed conditioning: France; origin: USA; reference: DJ0512). The one-thousand seed weight was $273 \mathrm{~g}$.

To evaluate salt tolerance during germination, a total of four replicates of ten seeds were disinfected with $1 \%$ $\mathrm{NaOCl}$, rinsed with distilled water and immediately sown on $0.8 \%$ (water agar) in $9 \mathrm{~cm}$ Petri dishes.

The water agar was prepared with various salts: $\mathrm{NaCl}, \mathrm{Na}_{2} \mathrm{SO}_{4}, \mathrm{CaCl}_{2}$, $\mathrm{CaCO}_{3}$ and $\mathrm{KCl}$, with concentrations of $0,100,200$ and $300 \mathrm{mM}$. Seeds were incubated at $25^{\circ} \mathrm{C}$, in the dark, for 10 days, because the seeds germinate favourably under these conditions (Mansouri and Kheloufi, 2017). Experiments was performed in a completely randomized block. Germination counts were done daily to evaluate the kinetics of germination. Seeds were considering germinating only when $2 \mathrm{~mm}$ radicles emerged (Fig. 1).

At the end of the germination period, the final germination percentage, the length of the taproot, the number of secondary roots, the dry weight of cotyledons and seedlings (without cotyledons) were recorded. The common bean root system is characterized by a taproot. Roots arising from it are called secondary roots, those formed from them is called tertiary roots. Adventitious roots were formed at the base of hypocotyl (Díaz-Ruiz, 2012). Cotyledons and seedlings were weighed separately after drying in an oven at $80^{\circ} \mathrm{C}$ for $48 \mathrm{hrs}$. Twelve replications were used for the growth traits, viz. three replicates from each Petri dish. 


\section{GERMINATION BEHAVIOR OF COMMON BEAN ACROSS A RANGE OF SALINITIES}

In the germination tests, final germination percentage (FGP) for each salt types and levels were calculated by using the following formula:

$$
F G P(\%)=\frac{\Sigma n i}{N} \times 100
$$

where, $F G P$ is final germination percentage, $n i$ is the number of germinated seeds at final day of test, and $N$ is the total number of incubated seeds per test (Côme, 1970).

\section{Statistical analysis}

The experiments were conducted with four replicates of ten seeds $(n=4 * 10)$ for the trait seed germination and with 12 replicates $(\mathrm{n}=12)$ for the morphological characteristics, and the results were expressed as mean \pm standard deviation (SD). All the data were subjected to one-way and two-way analysis of variance (ANOVA) and Duncan's multiple range test $(P<0.05)$ using SAS Version 9.0 (Statistical Analysis System) (2002) software.

\section{RESULTS AND DISCUSSION}

The results of analysis of variance indicated that the effects of salt types and concentrations, and their interaction effect were significant in all measured traits $(P<0.01)$ (Table 1). Mean comparison of simple effects of different salt types and concentrations and their interaction are shown in Table 2.

The mean comparison results and the results of analysis of variance (Table 2) showed that among different salts, the lowest inhibitory effects on germination and the most measured traits was belonged to $\mathrm{CaCO}_{3}$ and $\mathrm{KCl}$, and the highest inhibitory was related to $\mathrm{NaCl}, \mathrm{Na}_{2} \mathrm{SO}_{4}$ and $\mathrm{CaCl}_{2}$.
On the other hand, it is important that effect of salt concentration was obvious. The highest inhibitory effect was related to $300 \mathrm{mM}$ of all the salts (Table 2).

\section{Germination kinetics}

According to our results, the common bean seeds were able to germinate in the absence and/or in the presence of a low/high salinity, they are tolerant in the presence of salts; but, this tolerance differs from a treatment solution to the other one, because the type of salt plays a determining role grafting for the seed germination (Kheloufi et al., 2016b). The results represented on Fig. 2 indicate that under the saline conditions of the five kinds of salts $\left(\mathrm{NaCl}, \mathrm{Na}_{2} \mathrm{SO}_{4}, \mathrm{CaCl}_{2}, \mathrm{CaCO}_{3}\right.$ and $\mathrm{KCl}$ ), the kinetics of germination expresses three phases: a first phase of latency, expressed by the imbibition of seeds; a second exponential phase where one attends an acceleration of germination and finally a third phase characterized by a stationary stage indicating an interruption of germination. Finally, whatever the type of salt used, the germinative capacity of salt-stressed seeds is reduced and this for the three concentrations used.

Under saline conditions operated by $100 \mathrm{mM}$ of all the type of salt, the dynamics of the germinative capacity 
are slightly disturbed. The seeds expressed their sensitivity starting from the concentration of $200 \mathrm{mM}$ by expressing a very reduced germination rate with a very slow exponential phase and which lasts much longer to be stabilized at the $10^{\text {th }}$ day of the experiment. The concerned salts by this observation were only $\mathrm{NaCl}$, $\mathrm{Na}_{2} \mathrm{SO}_{4}, \mathrm{CaCl}_{2}$ and $\mathrm{CaCO}_{3}$ (Fig. 2). According to Rejili et al. (2010), the osmotic effects are translated by the inability of seeds to absorb sufficient amounts in water to return them to their critical threshold of moisture, necessary for the release of the process of germination; however, the toxic effects are bound to a cellular accumulation of salts, which cause disturbances of enzymes involved in the physiology of seed germination, prevent dormancy breaking of embryos and lead to a decrease in the capacity of germination.

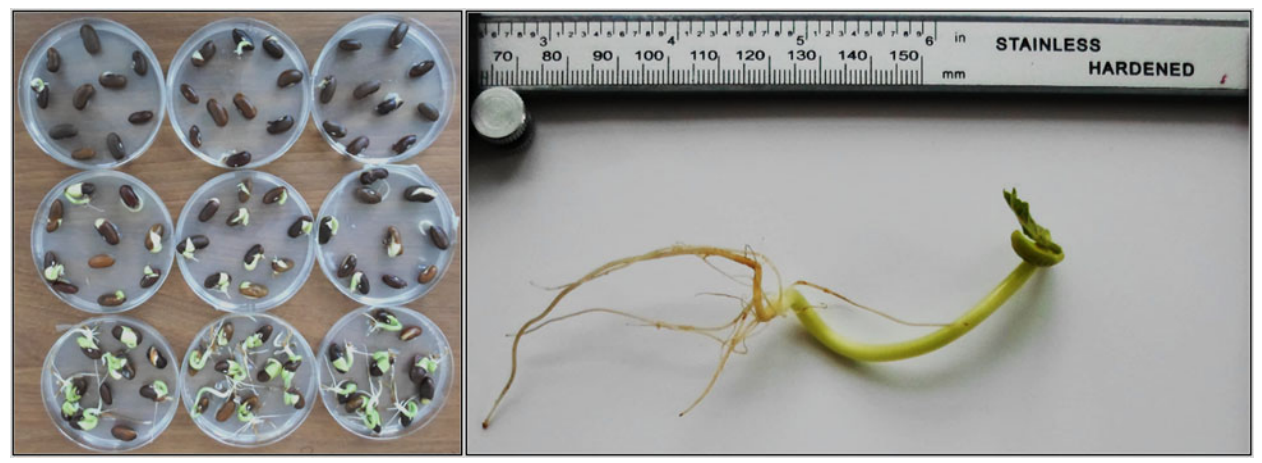

Figure 1 - Experimental design

\section{Final germination percentage}

According to Figure $3 A$, interpretation of interaction effect of salt types and concentrations on germination percentage showed that maximum germination was obtained under non-saline conditions (control treatment) $(87.5 \%)$. The lowest FGP was obtained under $300 \mathrm{mM}$ of all salts recording the following values: $60 \%(\mathrm{NaCl}), 60 \%\left(\mathrm{CaCO}_{3}\right), 52.5 \%$ $(\mathrm{KCl}), \quad 50 \% \quad\left(\mathrm{Na}_{2} \mathrm{SO}_{4}\right)$ and $27.5 \%$ $\left(\mathrm{CaCl}_{2}\right)$. This reduction in the FGP induced by an increase of salinity stress have been described by numerous authors for the same leguminous species (Beltagi et al.,
2006; Taffouo et al., 2010; Cokkizgin, 2012; Mena et al., 2015). Decrease in germination by increasing of salinity level was possibly due to reduced soluble osmotic potential, high toxic ions and seed nutrient imbalance $(\mathrm{Hu}$ and Schmidhalter, 2005). It is also assumed that in addition to toxic effects of certain ions, higher concentration of salt, reduces the water potential in the medium, which hinders water absorption by germinating seeds and thus reduces germination (Jamil et al., 2006; Tavakkoli et al., 2010).

Germination of common bean seeds by various salts were in the 
order of $\mathrm{NaCl}>\mathrm{KCl}>\mathrm{CaCO}_{3}>$ $\mathrm{Na}_{2} \mathrm{SO}_{4}>\mathrm{CaCl}_{2}$ (Table 2).

Kaymakanova (2009) also showed that the three studied cultivars of $P$. vulgaris were inhibited stronger by $\mathrm{Na}_{2} \mathrm{SO}_{4}$ than $\mathrm{NaCl}$ treatment. This can be attributed to the fact that different salts have different inhibitory effects on induction of germination suppression by lowering the osmotic potential of the medium (Moghaddam et al., 2018).

Most studies showed that the effect of salts on the germination is primarily osmotic and few researchers showed that it could be both ionic and osmotic (Duan et al., 2004; Joshi et al., 2005; Zhang et al., 2010).
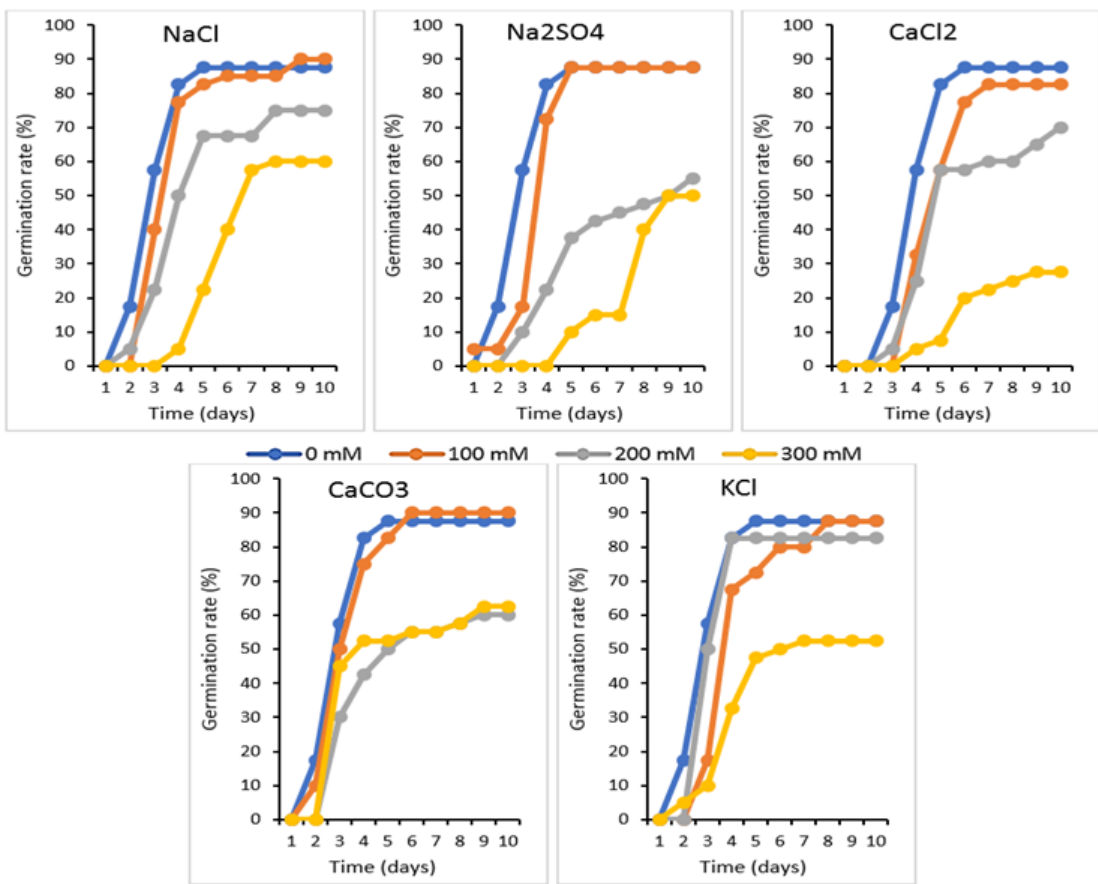

Figure 2 - Effect different type of treatment solution $\left(\mathrm{NaCl}, \mathrm{Na}_{2} \mathrm{SO}_{4}, \mathrm{CaCl}_{2}, \mathrm{CaCO}_{3}\right.$ and

$\mathrm{KCl})$ at various concentrations of $(0,100,200$ and $300 \mathrm{mM})$ on the germination kinetics of Phaseolus vulgaris var. Djedida after 10 days of incubation in Petri dish

\section{Length of the taproot}

The root length are the most important parameters for salt stress, because roots are in direct contact with soil and absorb water from soil and supply it to the rest of the plant. For this reason, root length provides an important trait in response to salt stress (Munns, 2011; Kheloufi et al., 2018). The length of the taproot showed a highly significant difference among the interaction effect of various salts and different salinity concentrations (Fig. 3B). 
By increasing of the salinity levels, the length of the taproot decreased. The highest root length was recorded in control treatment $(6.97 \mathrm{~cm})$ (Fig. 3B). The inhibitory effect of salts on root length have been found in our previous studies with three leguminous crops, viz. common bean, pea and chickpea (Mansouri and Kheloufi, 2017). The taproot length by various salts were in the order of $\mathrm{CaCO}_{3}>\mathrm{KCl}>\mathrm{NaCl}>$
$\mathrm{CaCl}_{2}>\mathrm{Na}_{2} \mathrm{SO}_{4}$ (Table 2). Decrease in plant height and other growth parameters are the most distinct and obvious effects of salt stress, since inhibition of growth is probably the most general response of plants to stress (Munns and Tester, 2008). Bayuelo-Jimenes (2002) reported that salt-tolerant species (accessions) of Phaseolus maintained relatively high root growth even at $180 \mathrm{mM}$ (nutrient solution) $\mathrm{NaCl}$.

Table 1 - Analysis of variance for the traits investigated for Phaseolus vulgaris var. Djedida in response to salinity stress using different type of treatment solution $\left(\mathrm{NaCl}, \mathrm{Na}_{2} \mathrm{SO}_{4}, \mathrm{CaCl}_{2}, \mathrm{CaCO}_{3}\right.$ and $\mathrm{KCl})$ at various concentrations of $(0,100,200$ and $300 \mathrm{mM})$

\begin{tabular}{ccccc}
\hline Parameters & $\begin{array}{c}\text { Source of } \\
\text { variables }\end{array}$ & $\begin{array}{c}\text { Degree of } \\
\text { freedom }\end{array}$ & F de Fisher & $\boldsymbol{P}$ \\
\hline \multirow{3}{*}{ FGP } & TRT & 3 & 56,48 & $<0,0001$ \\
\cline { 2 - 5 } & TYPE & 4 & 3,43 & 0,0136 \\
\cline { 2 - 5 } & TRT $\times$ TYPE & 12 & 2,74 & 0,0051 \\
\hline \multirow{3}{*}{ LTR } & TRT & 3 & 383,59 & $<0,0001$ \\
\cline { 2 - 5 } & TYPE & 4 & 39,25 & $<0,0001$ \\
\cline { 2 - 5 } & TRT $\times$ TYPE & 12 & 15,64 & $<0,0001$ \\
\hline \multirow{3}{*}{ SECROOT } & TRT & 3 & 70,27 & $<0,0001$ \\
\cline { 2 - 5 } & TYPE & 4 & 25,48 & $<0,0001$ \\
\cline { 2 - 5 } COTYDW & TRT $\times$ TYPE & 12 & 8,10 & $<0,0001$ \\
\cline { 2 - 5 } & TRT & 3 & 157,81 & $<0,0001$ \\
\cline { 2 - 5 } & TYPE & 4 & 37,42 & $<0,0001$ \\
\cline { 2 - 5 } & TRT $\times$ TYPE & 12 & 7,30 & $<0,0001$ \\
\cline { 2 - 5 } SLDW & TRT & 3 & 165,92 & $<0,0001$ \\
\cline { 2 - 5 } & TYPE & 4 & 173,03 & $<0,0001$ \\
\cline { 2 - 5 } & TRT $\times$ TYPE & 12 & 23,19 & $<0,0001$ \\
\hline \multirow{2}{*}{ TRY }
\end{tabular}

TRT - Salt concentration, FGP - Final germination percentage $\left(n=4^{*} 10\right)$, LTR Length of the taproot $(n=12)$, SECROOT - Number of secondary roots $(n=12)$, COTYDW - Cotyledon dry weight $(n=12)$, SLDW - Seedling dry weight $(n=12)$

\section{Number of secondary roots}

Developing a robust root system is crucial to plant survival and competition for soil resources (Schenk, 2006). There was a significant difference between various salts and each salinity level on secondary roots. The results of interaction effect showed that lateral roots were recorded mostly in control and $200 \mathrm{mM}$ of $\mathrm{CaCO}_{3}$ and $\mathrm{KCl}$ (Fig. 3C).

On the other hand, P. vulgaris seeds preserved the ability to produce secondary roots by increasing concentration to $300 \mathrm{mM}$ up to 12 
only in $\mathrm{CaCO}_{3}$. While, under the same level, the inhibitory effects of $\mathrm{Na}_{2} \mathrm{SO}_{4}$, $\mathrm{CaCl}_{2}, \mathrm{NaCl}$ and $\mathrm{KCl}$ were higher (Fig. 3C). According to the same figure, the highest value of secondary roots belonged to $100 \mathrm{mM} \mathrm{KCl}$. High salinity produces in plant a physiological drought. According to this, common bean duplicated the number of secondary and tertiary roots with modified architecture in response to drought (Nuñez-Barrios et al., 1998). No significance effect was found on secondary roots number under $\mathrm{CaCO}_{3}$ (Table 2).

A deep and extensive root system has been advocated to increase productivity of food legumes under drought and salinity conditions. Root length could be an important trait to assist in vitro selection of salinity resistant varieties of beans with an improved capacity to acquire water (Mena et al., 2015).

Duan et al. (2013) found that primary and lateral roots have intrinsically different response programs to salinity, with lateral roots having a stronger suppression than primary roots after salt treatment. Under high salinity, the production of abscisic acid (ABA) is induced and it is necessary for suppression of lateral roots.

The ability of the root system to control entry of ions to the shoot has crucial importance to plant survival in the presence of salt (Chinnusamy, 2005). In addition, high salinity may inhibit seedling and root elongation by slowing down the water uptake by the plant (Munns, 2002).

\section{Cotyledons dry weight}

During the germination process, the mobilization of seed reserves is initiated from the cotyledons to the embryonic axis (Bewley and Black, 1985). This process continues until the seedling stage, in which the primary sources are exhausted and the seedling becomes autotrophic to form leaves that carry out photosynthesis, which are the most important source of photosynthate of the plant (MunierJolain et al., 1998). The embryonic axis consists of the plumule and radicle, which demands nutrients from the seed when germination begins, which are provided by the cotyledons (Bewley and Black, 1985). The cotyledons dry biomass by various salts were in the order of $\mathrm{CaCl}_{2}>$ $\mathrm{NaCl}>\mathrm{Na}_{2} \mathrm{SO}_{4}>\mathrm{KCl}>\mathrm{CaCO}_{3}$ (Table 2).

The higher tolerance of cotyledon to salt stress may be an adaptive strategy of this species to survive with adverse environmental factors (Ruffino et al., 2010). Studies carried out by Wang et al. (2012) also indicated that cotyledons of Vicia cracca were more tolerant to $\mathrm{NaCl}$ stress than shoots.

According to Bathellier et al. (2008), during imbibition of the seed of $P$. vulgaris plants, cotyledons mass decrease slowly but after three days it was found that accelerated markedly. Cotyledons reduced its dry weight because they are the only structures that provide nutrients to the seedling (Díaz-Ruiz, 2012).

According to Fig. $3 D$, the reduction in dry biomass of 
cotyledons is proportional to germination rates and to the development of seedlings in dry biomass and in size. This establishes the relationships between growth of the shoot, root and provides nutrients from the cotyledons, which can be expressed by dry matter accumulation in the stem and root and to lose dry matter of cotyledons (Milberg and Lamont, 1997; Koyro et al., 2008). In the germination process, the cotyledons lose metabolic dry matter and conserved structural dry matter during the development of the seedling so that they become the only structures that die (Díaz-Ruiz, 2012).

Table 2 - Analysis of variance for each treatment solution

$\left(\mathrm{NaCl}, \mathrm{Na}_{2} \mathrm{SO}_{4}, \mathrm{CaCl}_{2}, \mathrm{CaCO}_{3}\right.$ and $\mathrm{KCl}$ ) used to investigate the response of Phaseolus vulgaris var. Djedida to salinity stress

\begin{tabular}{|c|c|c|c|c|c|}
\hline $\begin{array}{l}\text { Treatment } \\
\text { solution }\end{array}$ & Parameters & $\begin{array}{l}\text { Source of } \\
\text { variables }\end{array}$ & $\begin{array}{l}\text { Degree of } \\
\text { freedom }\end{array}$ & F de Fisher & $P$ \\
\hline \multirow{5}{*}{$\mathrm{NaCl}$} & FGP & TRT & 3 & 9.31 & 0.0019 \\
\hline & LTR & TRT & 3 & 101.33 & $<0,0001$ \\
\hline & SECROOT & TRT & 3 & 15.32 & $<0,0001$ \\
\hline & COTYDW & TRT & 3 & 50.00 & $<0,0001$ \\
\hline & SLDW & TRT & 3 & 84.97 & $<0,0001$ \\
\hline \multirow{5}{*}{$\mathrm{Na}_{2} \mathrm{SO}_{4}$} & FGP & TRT & 3 & 18.86 & $<0,0001$ \\
\hline & LTR & TRT & 3 & 290.04 & $<0,0001$ \\
\hline & SECROOT & TRT & 3 & 36.15 & $<0,0001$ \\
\hline & COTYDW & TRT & 3 & 50.14 & $<0,0001$ \\
\hline & SLDW & TRT & 3 & 119.20 & $<0,0001$ \\
\hline \multirow{5}{*}{$\mathrm{CaCl}_{2}$} & FGP & TRT & 3 & 17.62 & 0.0001 \\
\hline & LTR & TRT & 3 & 141.49 & $<0,0001$ \\
\hline & SECROOT & TRT & 3 & 33.54 & $<0,0001$ \\
\hline & COTYDW & TRT & 3 & 36.50 & $<0,0001$ \\
\hline & SLDW & TRT & 3 & 82.16 & $<0,0001$ \\
\hline \multirow{5}{*}{$\mathrm{CaCO}_{3}$} & FGP & TRT & 3 & 6.97 & 0.0057 \\
\hline & LTR & TRT & 3 & 12.03 & $<0,0001$ \\
\hline & SECROOT & TRT & 3 & 1.15 & 0.3449 \\
\hline & COTYDW & TRT & 3 & 4.54 & 0.0092 \\
\hline & SLDW & TRT & 3 & 2.77 & 0.0578 \\
\hline \multirow{5}{*}{$\mathrm{KCl}$} & FGP & TRT & 3 & 15.11 & 0.0002 \\
\hline & LTR & TRT & 3 & 129.21 & $<0,0001$ \\
\hline & SECROOT & TRT & 3 & 23.18 & $<0,0001$ \\
\hline & COTYDW & TRT & 3 & 77.80 & $<0,0001$ \\
\hline & SLDW & TRT & 3 & 74.13 & $<0,0001$ \\
\hline
\end{tabular}

TRT - Salt concentration, FGP - Final germination percentage $\left(n=4^{*} 10\right)$, LTR - Length of the taproot $(n=12)$, SECROOT - Number of secondary roots $(n=12)$, COTYDW - Cotyledon dry weight $(n=12)$,

SLDW - Seedling dry weight $(n=12)$ 


\section{Seedling dry weight}

According to the Fig. 3E, the maximum seedling dry weight was related to $100 \mathrm{mM}$ of $\mathrm{CaCO}_{3}$ (89.94 $\mathrm{mg}$ ), while the minimum was recorded in $100 \mathrm{mM}$ of $\mathrm{Na}_{2} \mathrm{SO}_{4}$ $(1.18 \mathrm{mg})$. Indeed, under a treatment solution of $\mathrm{CaCO}_{3}$, the seedlings recorded the highest values under all the salinity levels and also compared to control. Then, the seedling dry biomass by various salts were in the order of $\mathrm{CaCO}_{3}>\mathrm{KCl}>\mathrm{NaCl}>$ $\mathrm{CaCl}_{2}>\mathrm{Na}_{2} \mathrm{SO}_{4}$.

Generally, the decreases in seedling growth, due to the increase in the salt concentration, are caused by physicochemical effects or by osmotic-toxic salts, which exist in saline solutions (Sarker et al., 2014). Reductions in the biomass of $P$. vulgaris under saline condition were indicative of severe growth limitations under $300 \mathrm{mM}$ (Fig. 3E), except for $\mathrm{CaCO}_{3}$ treatment solution. Salinity had adverse effects not only on the biomass, but also on other morphological parameters.

In several legumes, such as faba bean (Vicia faba) (Tammam, 2003; Bulut and Akıncı, 2010), soybean (Glycine max) (Panneerselvam et al.,
1998), and chickpea (Cicer arietinum) (Akhter et al., 2004), salinity was reportedly found to reduce seedling dry biomass. The reduction in seedling development may be due to toxic effects of the salt used, as well as unbalanced nutrient uptake by the seedlings (Jamil et al., 2006).

Bayuelo-Jiménez et al. (2002) indicate that the term 'salt tolerance during seed germination' is used only to refer to situations where the seed germinates rapidly under salt stress conditions. No distinction is made between osmotic and ionic effects of the salinity stress. Likewise, salt tolerance during early seedling growth is assessed on the absolute growth at a given salt concentration, as well as the percentage of growth under salt stress relative to growth under non-stress conditions. The same authors demonstrate that tolerance to salinity in Phaseolus species might also vary with developmental stages. Salt tolerance at germination and at the seedling stage appears to be controlled by more than one gene and is highly influenced by salt type and concentration (Yamaguchi and Blumwald, 2005; Munns, 2005).

(A)

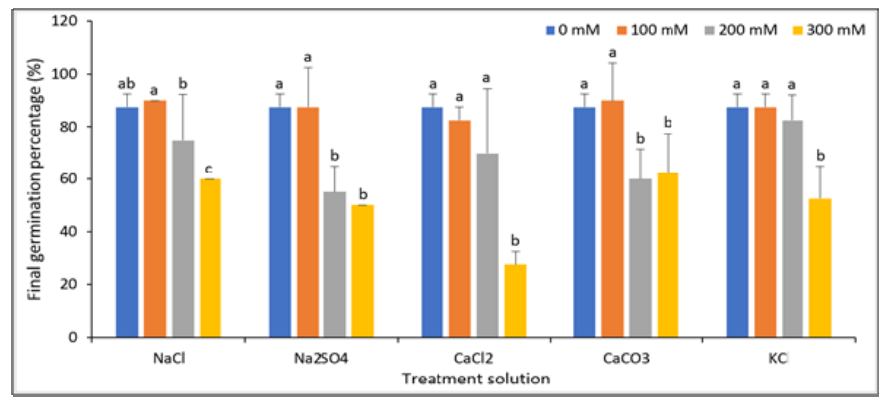


(B)

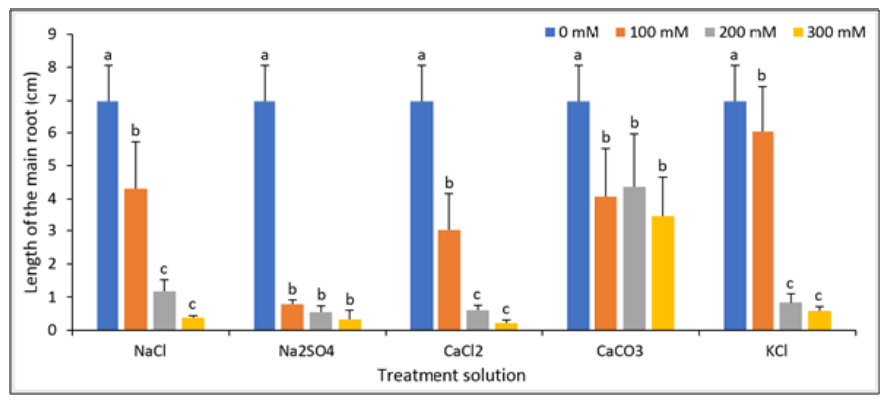

(C)

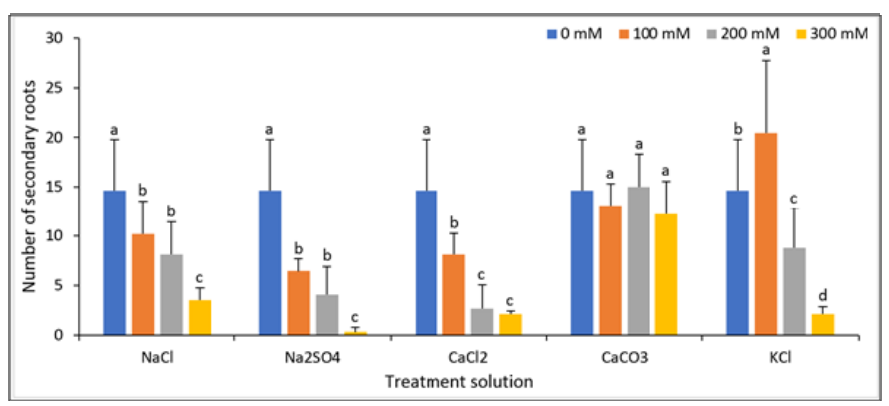

(D)
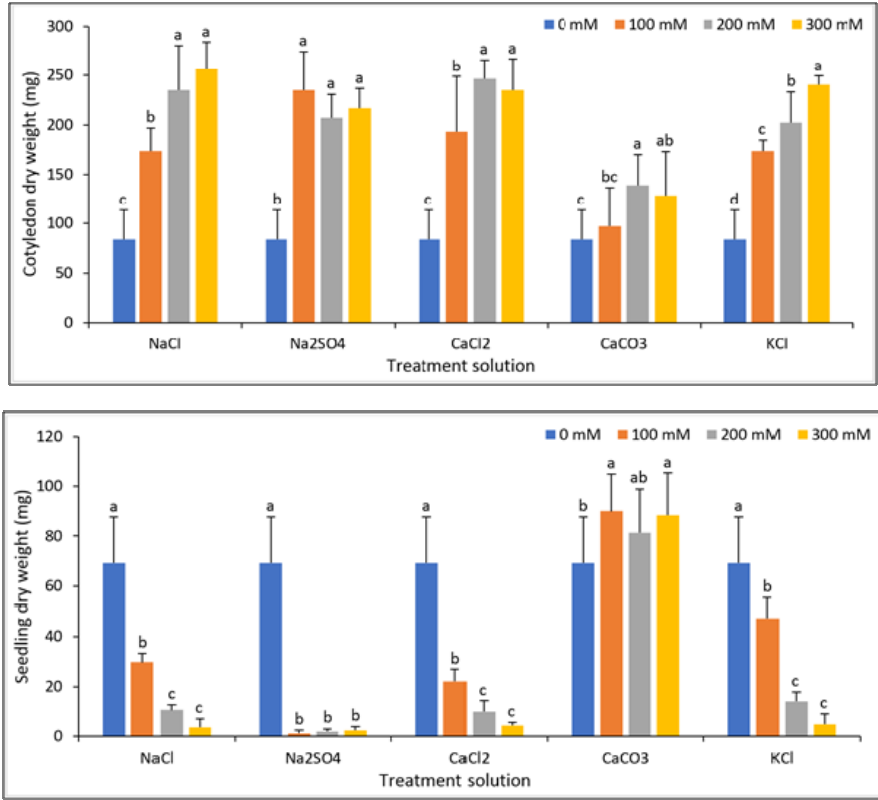

Figure 3 - Interaction effect of salt types and concentrations on: (A) Final germination percentage, (B) Length of the taproot, (C) Number of secondary roots, (D) Cotyledon dry weight and (E) Seedling dry weight in Phaseolus vulgaris var. Djedida after 10 days of incubation in Petri dish (For each treatment solution, means followed by the same letter are not significantly different at $5 \%$ probability level). 


\section{CONCLUSIONS}

During germination stage, the radicle emergence would be controlled by the environment osmolarity, while the later growth of the seedling would be limited by the reserve mobilization. It can be concluded that salt stress decreased seed germination and seedling length at early growth stage. As the results demonstrated, the inhibitory effects of the five salt types studied in the germination phase of common bean differed substantially, especially in the case of $\mathrm{NaCl}, \mathrm{CaCl}_{2}$ and $\mathrm{Na}_{2} \mathrm{SO}_{4}$. Inhibitory effects of these salts on common bean were very strong, compared to those of $\mathrm{CaCO}_{3}$ and $\mathrm{KCl}$. These differential behaviors of $P$. vulgaris var. Djedida seeds according to the salt types are presumably due to the fact that the same concentration of salt generates different osmotic potentials and the osmotic effect may have a greater influence on germination.

\section{REFERENCES}

Adda, A., Regagba, Z., Latigui, A. \& Merah, O. (2014). Effect of salt stress on $\alpha$-amylase activity, sugars mobilization and osmotic potential of Phaseolus vulgaris L. seeds var. 'Cocorose' and 'Djadida' during germination. J.Biol.Sci., 14(5): 370375, DOI: 10.3923/jbs.2014.370.375

Akhter, J., Mahmood, K., Malik, K.A., Mardan, A., Ahmad, M. \& Iqbal, M.M. (2004). Effects of hydrogel amendment on water storage of sandy loam and loam soils and seedling growth of barley, wheat and chickpea. Plant Soil Environ., 50(10): 463-469.

Bathellier, C., Badeck, F.W., Couzi, P., Harscoët, S., Mauve, C. \& Ghashghaie, J. (2008). Divergence in $\delta 13 \mathrm{C}$ of dark respired $\mathrm{CO}_{2}$ and bulk organic matter occurs during the transition between heterotrophy and autotrophy in Phaseolus vulgaris plants. New Phytologist, 177(2): 406-418, DOI: 10.1111/j. 1469-8137.2007.02246.x

Bayuelo-Jiménes, J.S., Debouck, D.G. \& Lynch, J.P. (2002). Salinity tolerance of Phaseolus species during early vegetative growth. Crop Sci., 42(6): 2184-2192, DOI: 10.2135/cropsci2002.2184

Beebe, S., Rao, I., Blair, M. \& AcostaGallegos, J. (2013). Phenotyping common beans for adaptation to drought. Front.Physiol., 4: 1-20, DOI: 10.3389/fphys.2013.00035

Beltagi, M.S., Ismail, M.A. \& Mohamed, F.H. (2006). Induced salt tolerance in common bean (Phaseolus vulgaris L.) by gamma irradiation. Pak.J.Biol.Sci., 9(6): 1143-1148, DOI: $10.3923 /$ pjbs.2006.1143.1148

Bernstein, L. \& Hayward, H.E. (1958). Physiology of salt tolerance. Annu.Rev.Plant Physiol., 9(1): 2546, DOI: 10.1146/annurev.pp.09.060 158.000325

Bevilaqua, G.A.P. \& Antunes, I.F. (2015). Chemical composition of whole grains in common beans landraces and breeding genotypes. Holos, (2): 81-91, DOI: 10.15628/ holos.2015.1996

Bewley, J.D. \& Black, M. (1985). Seeds. In: Seeds, Germination, Structure, and Composition, pp. 1-27. Springer, Boston, MA.

Bewley, J.D. \& Black, M. (2012). Physiology and biochemistry of seeds in relation to germination: Vol. 2: Viability, dormancy, and environmental control. Springer Science \& Business Media. 


\section{L.M. MANSOURI, N. HELEILI, Z.F. BOUKHATEM, A. KHELOUFI}

Blair, M.W. (2013). Mineral biofortification strategies for food staples: the example of common bean. J.Agric. Food Chem., 61(35): 8287-8294, DOI: $10.1021 / \mathrm{jf} 400774 \mathrm{y}$

Bouzid, S. \& Rahmoune, C. (2012). Enhancement of saline water for irrigation of Phaseolus vulgaris L. species in presence of molybdenum. Procedia Eng., 33: 168-173, DOI: 10.1016/j.proeng.2012.01.1190

Bradford, K.J. (1995). Water relations in seed germination. Seed Development and Germination, 1(13): 351-396.

Bulut, F. \& Akıncı, Ş. (2010). The effect of salinity on growth and nutrient composition in broad bean (Vicia faba L.) seedlings. Fresen.Environ. Bull., 19(12): 2901-2910.

Chinnusamy, V., Jagendorf, A. \& Zhu, J.K. (2005). Understanding and improving salt tolerance in plants. Crop Sci., 45(2): 437-448, DOI: 10.2135/cropsci2005.0437

Cokkizgin, A. (2012). Salinity stress in common bean (Phaseolus vulgaris L.) seed germination. Not.Bot.Horti Agrobo. Cluj-Napoca, 40(1): 177182. DOI: https://doi.org/10.15835/ nbha4017493

Côme, D. (1970). Obstacles to germination. Masson et Cie. (Eds.), Paris, $162 \mathrm{p}$

Díaz-Ruiz, R. (2012). The distribution of dry matter in bean seedlings in light and darkness conditions. Applied Photosynthesis, 335-352.

Duan, D., Liu, X., Khan, M.A. \& Gul, B. (2004). Effects of salt and water stress on the seed germination of Chenopodium glaucum L. seed. Pak.J.Bot., 36(4):793-800.

Duan, L., Dietrich, D., Ng, C.H., Chan, P.M.Y., Bhalerao, R., Bennett, M.J. \& Dinneny, J.R. (2013). Endodermal ABA signaling promotes lateral root quiescence during salt stress in Arabidopsis seedlings. The Plant Cell, 25(1): 324-341, DOI: 10.1105/tpc.112.107227
Faramarzi, M., Abbaspour, K.C., Vaghefi, S.A., Farzaneh, M.R., Zehnder, A.J., Srinivasan, R. \& Yang, H. (2013). Modeling impacts of climate change on freshwater availability in Africa. J.Hydrol., 480: 85-101, DOI: 10.1016/j.jhydrol.2012. 12.016

Finch-Savage, W.E. \& Bassel, G.W. (2015). Seed vigour and crop establishment: extending performance beyond adaptation. J.Exp.Bot., 67(3): 567-591, DOI: 10.1093/jxb/erv490

Galford, G.L., Melillo, J., Mustard, J.F., Cerri, C.E.P. \& Cerri, C.C. (2010). The Amazon frontier of land-use change: croplands and consequences for greenhouse gas emissions. Earth Interact., 14: 1-24, DOI: 10.1175/2010EI327.1

Hu, Y. \& Schmidhalter, U. (2005). Drought and salinity: a comparison of their effects on mineral nutrition of plants. J. Plant Nutr.Soil Sci., 168(4): 541-549, DOI: 10.1002/jpln.200420 516

Jamil, M., Deog Bae, L., Kwang Yong, J., Ashraf, M., Sheong Chun, L. \& Eui Shik, R. (2006). Effect of salt $(\mathrm{NaCl})$ stress on germination and early seedling growth of four vegetables species. J.Centr.Eur Agric., 7(2): 273-282.

Joshi, A.J., Mali, B.S. \& Hinglajia, H. (2005). Salt tolerance at germination and early growth of two forage grasses growing in marshy habitats. Environ.Exp.Bot., 54(3): 267-274, DOI: 10.1016/j.envexpbot.2004.09. 005

Kaymakanova, M. (2009). Effect of salinity on germination and seed physiology in bean (Phaseolus vulgaris L.). Biotechnol.Biotec.Eq., 23(sup.1): 326-329, DOI: 10.1080/ 13102818.2009.10818430

Kheloufi, A., Chorfi, A. \& Mansouri, L.M. (2017). Germination kinetics in two Acacia karroo hayne ecotypes under salinity conditions. OALib.J., 4: 1-11, DOI: 10.4236/oalib.1103319 
Kheloufi, A., Chorfi, A. \& Mansouri, L.M. (2016a). Comparative effect of $\mathrm{NaCl}$ and $\mathrm{CaCl} 2$ on seed germination of Acacia saligna $\mathrm{L}$. and Acacia decurrens Willd. Int.J.Biosci., 8(6): 113, DOI: 10.12692/ijb/8.6.1-13

Kheloufi, A., Chorfi, A. \& Mansouri, L.M. (2016b). The Mediterranean seawater: the impact on the germination and the seedlings emergence in three Acacia species. J.Bio.Env.Sci., 8(6): 238-249.

Kheloufi, A., Chorfi, A., Mansouri, L.M. \& Benyamina, H. (2018). Morphophysiological characterization and photosynthetic pigment contents of Acacia karroo hayne seedlings under saline conditions. Agricult. Forest., 64(2): 87-99, DOI: 10.177 07/AgricultForest.64.2.06

Koyro, H.W., Lieth, H. \& Eisa, S.S. (2008). Salt tolerance of Chenopodium quinoa Willd., grains of the Andes: Influence of salinity on biomass production, yield, composition of reserves in the seeds, water and solute relations. Mangroves and Halophytes: Restoration and Utilisation, 133-145. Springer, Dordrecht.

Kusvuran, S., Kiran, S. \& Ellialtioglu, S.S. (2016). Antioxidant enzyme activities and abiotic stress tolerance relationship in vegetable crops. Arun K. Shanker (Ed.), Abiotic and biotic stress in plants-recent advances and future perspectives. Publisher: Intech, Chitra Shanker, 481-506, DOI: $10.5772 / 62235$

Lobell, D.B. (2014). Climate change adaptation in crop production: beware of illusions. Glob. Food Sec. 3(2): 72-76, DOI: 10.1016/j.gfs.2014. 05.002

Mansouri, L.M. \& Kheloufi, A. (2017). Effect of diluted seawater on seed germination and seedling growth of three leguminous crops (pea, chickpea and common bean). Agricult.Forest, 63(2): 131-142, DOI: 10.17707/AgricultForest.63.2.11
Mena, E., Leiva-Mora, M., Jayawardana, E.K.D., García, L., Veitía, N., Bermúdez-Caraballoso, I., Collado, R. \& Ortíz, R.C. (2015). Effect of salt stress on seed germination and seedlings growth of Phaseolus vulgaris L. Cult.Trop., 36(3): 71-74.

Milberg, P. \& Lamont, B.B. (1997). Seed/cotyledon size and nutrient content play a major role in early performance of species on nutrientpoor soils. New Phytol., 137(4): 665672, DOI: 10.1046/j.1469-8137. 1997.00870.x

Moghaddam, M., Babaei, K. \& Saeedi Pooya, E. (2018). Germination and growth response of flax (Linum usitatissimum) to salinity stress by different salt types and concentrations. J. Plant Nutr., 41(5): 563-573, DOI: 10.1080/01904167 .2017 .1392573

Munier-Jolain, N.G., Munier-Jolain, N.M., Roche, R., Ney, B. \& Duthion, C. (1998). Seed growth rate in grain legumes I. Effect of photoassimilate availability on seed growth rate. J.Exp.Bot. 49(329): 1963-1969, DOI: $10.1093 / \mathrm{jxb} / 49$. 329.1963

Munns, R. (2002). Comparative physiology of salt and water stress. Plant Cell Environ., 25(2): 239-250, DOI: $\quad 10.1046 / \mathrm{j} .0016-8025.2001$. 00808.x

Munns, R. (2005). Genes and salt tolerance: bringing them together. New Phytol., 167: 645-663, DOI: 10.1111/j.1469-8137.2005.01487.x

Munns, R. (2011). Plant adaptations to salt and water stress: differences and commonalities. Adv.Bot.Res., 57: 1-32, DOI: 10.1016/B978-0-12387692-8.00001-1

Munns, R. \& Termaat, A. (1986). Wholeplant responses to salinity. Aust.J. Plant Physiol., 13(1): 143-160, DOI: 10.1071/PP9860143

Munns, R. \& Tester, M. (2008). Mechanisms of salinity tolerance. Annu.Rev.Plant Biol., 59: 651-681, 


\section{L.M. MANSOURI, N. HELEILI, Z.F. BOUKHATEM, A. KHELOUFI}

DOI: 10.1146/annurev.arplant.59.03 2607.092911

Nuñez-Barrios, A.N., Ritchie, J. \& Smucker, A.J. (1998). El efecto de sequía en el crecimiento, la fotosíntesis y la intercepción de luz en frijol común (Effect of drought on photosynthesis, growth, and light interception in dry beans). Agron. Mesoam., 9(2): 1-8, DOI 10.15517/am.v9i2.19463

Panneerselvam, R., Muthukumarasamy, M. \& Rajan, S.N. (1998). Amelioration of $\mathrm{NaCl}$ stress by triadimefon in soybean seedlings. Biol.Plant., 41(1): 133-137.

Parihar, P., Singh, S., Singh, R., Singh, V.P. \& Prasad, S.M. (2015). Effect of salinity stress on plants and its tolerance strategies: a review. Envir. Sci.Pollut.Res., 22(6): 4056-4075, DOI: $10.1007 / \mathrm{s} 11356-014-3739-1$.

Rejili, M., Vadel, A.M., Guetet, A., Mahdhi, M., Lachiheb, B., Ferchichi, A. \& Mars, M. (2010). Influence of temperature and salinity on the germination of Lotus creticus (L.) from the arid land of Tunisia. Afr.J.Ecol., 48(2): 329-337, DOI: 10.1111/j.1365-2028.2009.01111.x

Ruffino, A.M.C., Rosa, M., Hilal, M., González, J.A. \& Prado, F.E. (2010). The role of cotyledon metabolism in the establishment of quinoa (Chenopodium quinoa) seedlings growing under salinity. Plant Soil, 326(1-2): 213-224, DOI: 10.1007/s11104-009-9999-8

Sarker, A., Hossain, M.I. \& Kashem, M.A. (2014). Salinity $(\mathrm{NaCl})$ tolerance of four vegetable crops during germination and early seedling growth. Int.J. Latest Res.Sci.Technol., 3(1): 91-95.

Schabes, F.I. \& Sigstad, E.E. (2005). Calorimetric studies of quinoa (Chenopodium quinoa Willd.) seed germination under saline stress conditions. Thermochim. Acta, 428(1-2): 71-75, DOI: 10.1016/j.tca. 2004.09.027
Schenk, H.J. (2006). Root competition: beyond resource depletion. J. Ecol., 94(4): 725-739, DOI: 10.1111/j.1365 $-2745.2006 .01124 . x$

Shannon, M.C. \& Grieve, C.M. (1998). Tolerance of vegetable crops to salinity. Sci.Hortic., 78(1-4): 5-38, DOI: 10.1016/S0304-4238(98)00189 $-7$

Sinclair, T.R. \& Vadez, V. (2012). The future of grain legumes in cropping systems. Crop Past.Sci., 63(6): 501512, DOI: $10.1071 / \mathrm{CP} 12128$

Taffouo, V. D., Meguekam, L., Akoa, A. \& Ourry, A. (2010). Salt stress effects on germination, plant growth and accumulation of metabolites in five leguminous plants. Nong $\mathrm{Ye} \mathrm{Ke}$ Xue Yu Ji Shu, 4(2): 27.

Taïbi, K., Taïbi, F., Abderrahim, L.A., Ennajah, A., Belkhodja, M. \& Mulet, J.M. (2016). Effect of salt stress on growth, chlorophyll content, lipid peroxidation and antioxidant defense systems in Phaseolus vulgaris L. S.Afr.J.Bot., 105: 306-312, DOI: 10.1016/j.sajb. 2016.03.011

Tammam, A.A. (2003). Response of Vicia faba plants to the interactive effect of sodium chloride salinity and salicylic acid treatment. Acta Agron.Hung., 51(3): 239-248, DOI: 10.1556/AAgr.51.2003.3.1

Tavakkoli, E., Rengasamy, P. \& McDonald, G.K. (2010). High concentrations of $\mathrm{Na}^{+}$and $\mathrm{Cl}^{-}$ions in soil solution have simultaneous detrimental effects on growth of faba bean under salinity stress. J.Exp.Bot., 61(15): 4449-4459, DOI: 10.1093/jxb/erq251

Tobe, K., Li, X. \& Omasa, K. (2002). Effects of sodium, magnesium and calcium salts on seed germination and radicle survival of a halophyte, Kalidium caspicum (Chenopodiaceae). Aust.J.Bot., 50(2): 163-169, DOI: 10.1071/BT0 1065

Tobe, K., Li, X. \& Omasa, K. (2004). Effects of five different salts on seed 


\section{GERMINATION BEHAVIOR OF COMMON BEAN ACROSS A RANGE OF SALINITIES}

germination and seedling growth of Haloxylon ammodendron (Chenopodiaceae). Seed Sci.Res., 14(4): 345-353, DOI: 10.1079/SSR2 004188

Wang, Y., Yang, J., Jiang, S., Tian, Y., Sun, H., Wang, M., Guangdi, L. \& Zhou, D. (2012). Comparison of inorganic solute accumulation in shoots, radicles and cotyledons of Vicia cracca during the seedling stage under $\mathrm{NaCl}$ stress. Soil Sci. Plant Nutr., 58(1): 24-31, DOI: 10.1080/00380768.2011.647606

Yamaguchi, T. \& Blumwald, E. (2005). Developing salt-tolerant crop plants: challenges and opportunities. Trends in Plant Sci., 10(12): 615-
620, DOI: 10.1016/j.tplants.2005. 10.002

Zandalinas, S.I., Mittler, R., Balfagón, D., Arbona, V. \& Gómez-Cadenas, A. (2018). Plant adaptations to the combination of drought and high temperatures. Physiol.Plant., 162(1): 2-12, DOI: 10.1111/ppl.12540

Zhang, H., Irving, L.J., McGill, C., Matthew, C., Zhou, D. \& Kemp, P. (2010). The effects of salinity and osmotic stress on barley germination rate: sodium as an osmotic regulator. Ann.Bot., 106(6): 10271035, DOI: 10.1093/aob/mcq204. 